quently impossible to say whether the substance formed is the desired compound or its mirror image. The mechanism of such interactions has been fully studied by E. Fischer in Berlin and A. McKenzie in London, and it was appropriate that the latter should give a concise though clear and logical summary of the question, which is generally spoken of as the Walden rearrangement, before the section. A considerable discussion ensued.

Dr. Lowry followed with a paper dealing with a closely allied subject, that of isomeric change, and more especially with those taking place in solutions of the crystalline amide and piperidide of camphorcarboxylic acid. This case is of exceptional complexity, since the experimental measurements show that three distinct isomeric changes take place, and that a condition of equilibrium is established ultimately between four distinct isomerides. The equations for consecutive unimolecular changes of this type were described at length, as well as the curves representing change, and they were afterwards discussed by Prof. Soddy and others.

The second part of Dr. Lowry's communication dealt with the use of certain models to explain Barlow and Pope's theory of molecular structure based on valency conceptions. A very fluent account was given of a difficult subject, which was closely followed by those present.

The next two papers, by Prof. K. J. P. Orton, of Bangor, and Prof. Holleman transferred attention to the laws of substitution in the benzene series. Prof. Holleman's status in this field is well known, and the section was fortunate in having his cooperation throughout the meeting. Prof. Orton dealt with the conversion of chloro-, bromo-, and nitro-aminobenzenes into the carbon substituted anilines and anilides, giving a detailed account of his recent work. Prof. Holleman described work carried out in conjunction with Mr. J. P. Wibaut on the nitration of the chlorotoluenes. He indicated the number of isomerides formed in the various cases, and showed both how to calculate approximately their proportions and how well these figures agreed with those determined experimentally by the laborious separation of the constituents of the mixture.

A brief communication by Dr. J. K. Wood, who acted as local secretary for the section, was of considerable interest. Leucine and similar amphoteric substances are in reality internal salts, the acidic and basic groups neutralising each other. When an acid or base is added, the internal salt is broken up and a true salt formed with the added acid or base. In the case of an optically active substance it should be possible to determine the rotation when the whole of the internal salt has just been broken up, and so calculate the acidic and basic constants of the amphoteric substance. Leucine is lævorotatory in aqueous solution, but on the addition of hydrochloric acid the solution becomes increasingly dextrorotatory. When about $\mathrm{I}^{\circ} 34$ equivalents of acid have been added, the effect of further addition is much smaller, and there is a sharp bend of the curve at this point corresponding with the complete disappearance of the internal salt.

Equally sharp results could not be obtained with sodium hydroxide, owing to racemisation being caused by the alkali.

The method can be used at all events qualitatively to measure the strength of the added acids; the weaker the acid the more concentrated it must be to break up the internal salt. By working with a common acid, various amphoteric substances may be compared.

Owing to the shortness of time, Prof. C. R. NO. 2246, VOL. 90]
Marshall gave a very brief account of the two papers standing in his name. The action of bromine on strychnine has been investigated with the object of preparing a dibromo compound as described by some authors, but this does not appear to exist. The second paper dealt with pentaerythritol tetranitrate.

The final communication on phototropy was delivered by the president, who showed specimens of phototropic compounds obtained in the course of investigations on salicylidene amines. Of a large number of such compounds examined, fourteen have been found to exhibit phototropy distinctly-that is, they change in colour on exposure to light. In studying the influence of temperature on the phenomenon, it has been found that while some are phototropic at temperatures up to their melting points, others have a limiting temperature, above which they are not phototropic, whilst in two cases compounds which are not phototropic at the ordinary temperature show this property below zero centigrade.

The explanation of phototropy is still outstanding; it has been considered in turn as due to intramolecular rearrangement, stereoisomerism and polymorphism. Another problem is the nature of the energy evolved when the darker-coloured phototrope in the absence of solar energy, or possibly also when under solar influence, returns to the lighter form : this remains for future investigation.

A novel and successful feature of the meeting on its less severe side was the sectional supper held on the Saturday.

E. F. A.

\section{THE DIFFUSION OF EDUCATION AND KNOWLEDGE. ${ }^{1}$}

THE educational status of a nation consists in the amount of literacy, number of teachers, and number of persons in its primary and secondary schools, and in its colleges and universities, relative to population. The status of knowledge may be indicated by the number of books, periodicals, and newspapers relative to population. This knowledge may take two forms, one gained through books, the other through periodicals and newspapers. One is knowledge in general; the other consists more in current information.

The question may be asked, if a community or country leads another in literacy, diffusion of education and knowledge; if, relative to its population, it has more pupils in school, more teachers, more students in colleges and universities, more books in its libraries to read, and more periodicals and newspapers to peruse, is not this country or community, as a whole, very probably better educated and more intelligent than the other country or community? While there are exceptions due to special conditions, we are disposed to answer this question in the affirmative.

Table I. indicates in a general way the diffusion of education and knowledge in some leading countries.

Column I gives the relative amount of illiteracy among army and navy recruits. As these are mostly adults, they probably represent best the real amount of illiteracy. Column 6 gives the number of publications (relative to population) in the list of the Smithsonian Institution in Washington. These publications are of the highest class, including journals issued by learned societies and governmental institutions.

Examining Table I., it will be seen that Switzerland is much in advance of all the other countries in general diffusion of education and knowledge, and

1 From a paper on "Mentality of Nations in Connection with Patho Social Conditions," by Atthur Macdonald, in The Open Court for August. 
Russia is last. Italy also is very low in these respects. France shows a high degree (next to Switzerland) of diffusion in university education (8I) and newspaper information (25I). Germany shows the lowest degree of illiteracy and publishes the largest number of books, but not relative to its population. Denmark issues the largest number of books relative to population.

The United States, compared with European nations, is next to highest (Switzerland) in number of newspapers issued, but next to lowest (Russia) in number of university students enrolled and books produced, relative to population.

Since we are disposed often to estimate countries as to their mental status or literary production without reference to their population, we will compare the countries in Table 1 . according to the absolute number of books, periodicals, and newspapers published, as given in columns 7,8 , and 9 .
Denmark, which is behind France, Great Britain, and the Netherlands. There is no further correspondence of these three highly literate countries in the other educational columns.

In brief, there appears to be but little necessary relation in these countries between degrees of education and amount of literary production. Thus, Italy, with its great illiteracy, stands very high in university education. This is interesting in connection with the fact that Italy is doing some of the best work in sociology, which is suggestive in connection with the further fact that she stands next to the highest in production of sociological works.

The United States has a large percentage of illiteracy, vet ranks highest in percentage of population enrolled in schools, but has the smallest number of university students. It has next to the largest number of newspapers, but produces next to the

TABLE I.

\begin{tabular}{|c|c|c|c|c|c|c|c|c|c|c|c|}
\hline \multirow{2}{*}{\multicolumn{3}{|c|}{$\begin{array}{c}\text { Country } \\
1908\end{array}$}} & \multicolumn{3}{|c|}{ Education } & \multicolumn{6}{|c|}{ Knowledge and information } \\
\hline & & & $\begin{array}{l}\text { Number of } \\
\text { illiterates } \\
\text { per ro, ooo } \\
\text { recruits }\end{array}$ & $\mid \begin{array}{c}\text { Per cent. of } \\
\text { population } \\
\text { enrolled in } \\
\text { schools }\end{array}$ & $\begin{array}{c}\text { Number of } \\
\text { university } \\
\text { students } \\
\text { per ro, , } \\
\text { population }\end{array}$ & $\begin{array}{l}\text { Number of } \\
\text { newspapers } \\
\text { per million } \\
\text { population }\end{array}$ & $\begin{array}{c}\text { Number of } \\
\text { books pub- } \\
\text { lished per } \\
\text { roo,ooo } \\
\text { population }\end{array}$ & $\begin{array}{c}\text { Smithsonian } \\
\text { list : } \\
\text { Number of } \\
\text { publications } \\
\text { per million } \\
\text { population } \\
\text { (Igo4) }\end{array}$ & $\begin{array}{c}\text { Number of } \\
\text { books } \\
\text { published }\end{array}$ & $\begin{array}{c}\text { Number of } \\
\text { newspapers and } \\
\text { periodicals } \\
\text { issued (year) }\end{array}$ & $\begin{array}{l}\text { Smithsonian } \\
\text { list : } \\
\text { Number of } \\
\text { publications } \\
\text { (1904) }\end{array}$ \\
\hline Column & $\cdots$ & $\cdots \quad \cdots$ & $x$ & 2 & 3 & 4 & 5 & 6 & 7 & 8 & 9 \\
\hline $\begin{array}{l}\text { Belgium ... } \\
\text { Denmark. } \\
\text { France ... } \\
\text { Germany... } \\
\text { Great Britain } \\
\text { Italy ... } \\
\text { Netherlands } \\
\text { Russia ... } \\
\text { Switzerland . }\end{array}$ & $\begin{array}{l}\ldots \\
\cdots \\
\cdots \\
\cdots \\
\text { and } \\
\cdots \\
\cdots \\
\cdots \\
\cdots\end{array}$ & \begin{tabular}{cc|}
$\cdots$ & $\cdots$ \\
$\cdots$ & $\cdots$ \\
$\cdots$ & $\cdots$ \\
$\ldots$ & $\cdots$ \\
Ireland \\
$\ldots$ & $\cdots$ \\
$\cdots$ & $\cdots$ \\
$\cdots$ & $\cdots$ \\
$\cdots$ & $\cdots$
\end{tabular} & $\begin{array}{r}833^{1} \\
20^{2} \\
346^{1} \\
4^{1} \\
100^{1} \\
3072^{3} \\
210 \\
6110^{4} \\
9\end{array}$ & $\begin{array}{l}12 \cdot 2 \\
13 \cdot 0 \\
14^{\circ} \cdot 2 \\
17 \cdot 0 \\
17 \cdot 0 \\
8 \cdot 1 \\
15 \cdot 0 \\
4 \cdot 5^{5} \\
18 \cdot 6\end{array}$ & $\begin{array}{r}68 \\
81 \\
65 \\
56 \\
77 \\
72 \\
16 \\
178\end{array}$ & $\begin{array}{r}27 \\
84 \\
251 \\
\text { II } 5 \\
98 \\
60 \\
132 \\
8 \\
275\end{array}$ & $\begin{array}{r}28 \\
135 \\
28 \\
49 \\
22 \\
21 \\
56 \\
16\end{array}$ & $\begin{array}{r}48 \\
42 \\
42 \\
39 \\
45 \\
24 \\
36 \\
3 \\
90\end{array}$ & $\begin{array}{r}2763 \\
3519 \\
8799 \\
33317 \\
9821 \\
6918 \\
3258 \\
23852 \\
4256\end{array}$ & $\begin{array}{r}209(1908) \\
220(1908) \\
9877(1908) \\
7000(1907) \\
4400(1905) \\
2067(1904) \\
760(1906) \\
2220(1905) \\
1005(1907)\end{array}$ & $\begin{array}{r}354 \\
\text { II } 2 \\
\text { I } 723 \\
2390 \\
2038 \\
834 \\
207 \\
515 \\
35^{I}\end{array}$ \\
\hline United States. & s... & $\begin{array}{ll}\cdots & \cdots\end{array}$ & $3^{8} 80^{6}$ & $19 \% 7$ & 20 & 260 & 10 & 一 & 9254 & $21320(1908)$ & - \\
\hline
\end{tabular}

1 r904. $2{ }_{1897} \quad 3$ In white male population 21 to 24 years of age in rgoo.
were able to read.

As to largest number of books the rank is Germany, Russia, Great Britain, United States, France, Italy, Switzerland, \&c.

As to number of newspapers and periodicals, United States is unique, publishing twice as many as France (next in rank), and from three to ten times as many as some of the other countries.

As to the Smithsonian list of publications, the rank is Germany, Great Britain, France, Italy, Russia, Belgium, Switzerland, \&c.

If we take the extremely illiterate countries, as Russia, Italy, and Belgium, we find a correspondingly low percentage of the population enrolled in the public schools and a relatively low percentage of newspapers published. But when we come to the number of university students enrolled, the correspondence fails as to Italy and Belgium, which have, relative to population, a larger number of university students than Germany or Great Britain. As to the number of books published relative to population, the correspondence fails in the case of Belgium, which produces as many books as France (column 5), relative to its population. As to the Smithsonian list of publications, the correspondence fails in the case of Belgium, which is next to the highest (column 6).

If, now, the countries distinctly the least illiterate, as Germany, Switzerland, and Denmark, are compared in respect to enrolment in schools or primary education, the correspondence fails in the case of NO. 2246 , vOL. 90] smallest number of books. Russia, about which data are more difficult to obtain, stands lowest in all respects relative to its population.

Different countries naturally do not classify books in the same way, and sometimes one country will include under one head publications that other nations would place under another subject, and hence results given in Table II. must be taken in a general way.

In order to render the table more trustworthy, we have included two or more subjects under one head. For instance, under "History," both "Biography", and "Geography"; under "Literature," "Poetry," "Fiction," and "Drama," and under "Religion," "Theology." "Fiction" is both put by itself and also combined with "Literature."

A few headings could not be classified nor combined with others and were omitted, so that the table is not complete, but the percentage for each subject given is, of course, not affected.

It may be interesting to note the kind of books some countries prefer, as shown in Table II. Thus, France publishes relatively more medical works ( $10^{\circ} 5$ ) than any other nation here mentioned. Italy is second $\left(7^{\circ}\right)$ and Germany third $\left(5^{\circ}\right)$ in this subject. Belgium publishes relatively the most law books, Denmark the fewest. United States, Denmark, and Germany lead in religious works. Denmark and France excel in literature, and Germany and Italy in educational works, and France in books on military science. 
November 14, I912]

NATURE

TABle II.-Book Production-Per Cent. for Each Subject.

\begin{tabular}{|c|c|c|c|c|c|c|c|c|c|c|c|c|}
\hline Country 1908 & Medicine & Law & $\begin{array}{l}\text { Philo- } \\
\text { sophy }\end{array}$ & Religion & History & Sociology & Literature & $\underset{\text { Edion }}{\text { Educa- }}$ & Art & Science & $\begin{array}{l}\text { Military } \\
\text { science }\end{array}$ & Fiction \\
\hline Belgium ... .. & $5 \% 7$ & $7^{\circ} 0$ & $2 \cdot 6$ & $3 \cdot 8$ & I3.4 & $8 \cdot 6$ & $17 \cdot 3$ & $3 \cdot 8$ & $6 \cdot 2$ & $7^{\circ} \mathrm{O}$ & $I \cdot I$ & - \\
\hline Denmark $\quad \ldots$ & 37 & I'I & $I \cdot 2$ & $9 \cdot 6$ & - & - & 232 & $3 \cdot 3$ & 22 & $9 \cdot 7$ & - & 一 \\
\hline France $\quad \ldots \quad \ldots$ & $10 \cdot 5$ & $6 \cdot 3$ & $2 \cdot 1$ & $7 \cdot 3$ & $17 \cdot 3$ & $6 \cdot 4$ & $22 \cdot 0$ & 114 & $I^{\prime} \cdot 2$ & $4 \cdot 5$ & 39 & - \\
\hline Germany $\ldots . .$. & $5^{\cdot 8}$ & $10 \cdot 0^{1}$ & $2 \cdot 3$ & $8 \cdot 4$ & 9.0 & $10^{0} 0^{1}$ & 19.5 & $13 \cdot 8$ & $2 \cdot 9$ & 57 & 23 & $13 \cdot 7^{4}$ \\
\hline United Kingdom & $3 \cdot 1$ & $2 \cdot 6$ & - & $9 \cdot 5^{2}$ & 13.9 & $6 \% 7$ & I8:4 & $6 \cdot 4$ & - & II' 8 & - & $2 \cdot 6$ \\
\hline Italy $\quad \ldots \quad \ldots$ & $7 \cdot 6$ & 49 & $2 \cdot 8$ & 4.4 & 12.0 & $6 \cdot 7$ & I $4 \cdot \mathrm{I}$ & 13.1 & $2 \cdot 6$ & $5 \cdot 8^{3}$ & I 9 & $6 \cdot 3$ \\
\hline Netherlands ... & $3 \cdot 3$ & $5 \cdot 3$ & - & $6 \cdot 2$ & $\sim$ & $5 \cdot 3$ & - & 9.3 & - & $5 \cdot 3^{3}$ & - & - \\
\hline Russia $\quad \ldots \quad \ldots$ & $4 \cdot 6$ & $3 \cdot 1$ & - & $6 \cdot 8$ & 30 & - & $10 \cdot 2$ & 79 & - & $2 \cdot 5$ & - & $\bar{c}$ \\
\hline United States... & $3 \cdot 6$ & 9.9 & I'9 & 88 & 147 & $5 \cdot 9$ & $13 \cdot 3$ & $4 \cdot 5$ & $2 \cdot 5$ & $5 \cdot 1$ & 一 & $160^{\circ} 0$ \\
\hline
\end{tabular}

1 Law and political science.

2 Religion and philosophy.

3 Science and technology.

4 Belles lettres.

Although correspondence between mental and pathosocial conditions, or concomitant relations, does not necessarily indicate causal connection, yet it is interesting to note a few instances. In general, those countries which have the greatest illiteracy, as Italy, Belgium, and France, show the highest percentage of murder. They also have a high percentage of stillbirths, death-rate, and death-rate under one year of age. Two of these countries, where the illiteracy is more pronounced, as in Italy and Belgium, show a low rate of suicide and divorce. On the other hand, the least illiterate countries, as Germany, Switzerland, and Denmark, have a high rate of suicides.

\section{UNIVERSITY AND EDUCATIONAL INTELLIGENCE.}

Birmingham.-The chair of midwifery recently vacated by Dr. Edward Malins has been filled by the appointment thereto of Dr. Thomas Wilson, who has previously held the post of lecturer in this subject.

Cambridge.-Prof. R. C. Punnett has been selected by the Prime Minister and Mr. A. J. Balfour as the first Arthur Balfour professor of genetics.

A prize of $50 l$. out of the Gordon Wigan Fund will be awarded at the end of the Easter term, I9r3, for a research in chemistry, of sufficient merit, carried out in the University of Cambridge. The research may be in any branch of chemistry. The dissertation, with the details of the research, must be sent to the professor of chemistry not later than June I3, I9I3.

The current number of The Reporter contains revised schedules of the special examination in geography for the ordinary degree, and for the examination for the diploma in geography. It.also contains the list of subjects for the special examination in military subjects for next year.

OXFORD.-On November is Convocation will be asked to assent to a decree providing that a plot of land on the south side of the University Park, and another plot at the north-west angle of the park, be assigned for the purposes respectively of a chemical and an engineering laboratory. It is possible that the proposals will meet with opposition, as many members of the University are averse from further encroachments on the space available for recreation. At a later date statutes will be submitted to Congregation amending the present constitution (I) of the Hebdomadal Council by abolishing the existing division into "Orders" of its elected members, and (2) of Congregation, by abolishing the present qualification of residence, and enacting that in future Congregation shall consist of the teaching and administrative elements in the University and colleges. Another proposed statute provides, in certain circumstances, for a poll of Convocation to be kept open for three days. NO. 2246, VOL. 90]
It is thought that the second at least of these proposals, i.e. that relating to Congregation, will be resisted.

The election to a fellowship at All Souls' College of a graduate distinguished in mathematics or natural science is a rare occurrence, hence it is specially worthy of record that Mr. D. B. Somervell, of Magdalen College, one of the latest elected fellows of All Souls', obtained honours in mathematical moderations in 1908 , and first-class honours in chemistry in I9II.

The new Pharmacological Laboratory was formally opened on November 9 in the presence of the ViceChancellor and a large assemblage of Oxford medical graduates. The history of the department was briefly recounted by Sir William Osler, Regius professor of medicine, and an address on "The New Pharmacology" was delivered by the Reader, Dr. J. A. Gunn. Space for the new laboratory has been found by the insertion of a fioor in the rooms on the west front of the museum formerly occupied by the Radcliffe Library. Of the two stories thus formed, the upper is devoted to pharmacology, the lower is shared between the Hope department of entomology and the department of mineralogy.

Lieut.-Col. W. W. O. Beveridge, D.S.O., Royal Army Medical Corps, has been appointed professor of hygiene at the Royal Army Medical College, Grosvenor Road, S.W., in succession to Brevet-Col. C. H. Melville.

WE learn from Science that Mr. T. W. Todd, at present lecturer in anatomy at Victoria University of Manchester, has been appointed Henry Willson Payne professor of anatomy in the medical department of Western Reserve University in the United States. Prof. Todd will take up his new duties in December.

THE sum of ro,oool., free of Government duties, has been bequeathed by the late Misses Mary, Hannah, and Helen Dalgety and Mrs. Isabella Dalgety, or Wilson, to the University of Edinburgh for the foundation and endowment of bursaries not exceeding $50 l$. for two years and prizes in the law faculty of the University.

A MEETING of the governors of the South-Eastern Agricultural College, Wye, was held under the chairmanship of Lord Ashcombe, at Caxton House, on Monday, November Ir. The governors considered the proposed establishment of a fruit research plantation in the south-eastern district, and decided to accept the responsibility of administering such a plantation with the aid of the grant of $500 l$. offered by the Board of Agriculture.

THE council of the City and Guilds of London Institute has conferred the fellowship of the institute upon Mr. A. Chatterton and Mr. W. D. B. Duddell, F.R.S. This distinction is extended to those students who 